\title{
Characteristics of changes of the chemical composition of cranberry marsh in the process of obtaining puree
}

\author{
Vira Obolkina, Olena Kokhan, \\ Ivanna Syvnii, Iryna Krapyvnytska
}

National University of Food Technologies, Kyiv, Ukraine

Keywords:

Cranberry

Puree

Flavonoids

Anthocyanins

Preservatives

Article history:

Received 30.05.2018

Received in revised

form 29.08.2018

Accepted 27.12.2018

Corresponding author:

Vira Obolkina

E-mail:

vobol_ipdo@ukr.net

DOI: $10.24263 / 2304-$

974X-2018-7-4-7

\section{Abstract}

Introduction. Studies have been carried out to determine the impact of technological processing, in particular, on the processes of blanching and deaeration on the chemical composition of cranberry marsh puree.

Materials and methods. Puree of marsh cranberry was investigated for identification of bioflavonoid; methods of high-performance liquid chromatography, electron spectrometry, gas chromatography with mass detector of initial and hydrolyzed samples were used.

Results and discussion. It was established that as a result of technological reprocessing of cranberry into puree, the amount of ascorbic acid decreased by 13.5 times; the content of phenolic substances in puree from cranberry fruits is 983 $\mathrm{mg} \%$, anthocyanins $-160 \mathrm{mg} \%$; the content of water-soluble pectin is increased to $3.0 \%$, which is associated with partial hydrolysis of protopectin, fiber $-3.1 \%$ of the mass fraction of dry matter of puree. In puree from cranberries, $36.6 \%$ of sugars are contained in the mass fraction of dry matter of puree, of which $28.8 \%$ are reductive, namely glucose and fructose, the increase of which is due to partial acid hydrolysis of sucrose during the processing of berries in puree.

In puree, the presence of anthocyanin compounds found in the original sample is in a bound state with citric acid, as well as mono-oxycarboxylic acids. A number of organic acids have been identified: 3-hydroxybutyric acid; ferulic acid; amber, apple, citric acids. When processing cranberry into puree, it preserves natural preservatives contained in fresh berries. Thus, in cranberry puree there is benzoic acid in the amount of $122.2 \mathrm{mg} \% \pm 15 \%$ and a small amount of sorbic acid is available up to $2.5 \mathrm{mg} \%$. The positive effect of cranberry on growth retardation of the yeast of the genus Candida was investigated.

Conclusions. Cranberry puree is a natural source of biologically active substances and natural preservatives and is recommended for use in long-term storage functional foods. 


\section{Introduction}

An analysis of the current world trends in the creation of a new range of foods with high nutritional value has shown the feasibility of using berry raw materials [1]. Such raw materials include berries of cranberry marsh (Oxycoccus palustris Pers). This is a highyielding wild berry, rich in various groups of nutrients, which is dominated by a group of biologically active substances [2]. The value of wild berries is that the content of biologically active substances significantly exceeds the one that the cultivated berries contain [3].

In recent years, throughout the world, much attention has been paid to the study of the chemical composition and useful properties of this berry $[3,4,6]$. It is characterized by low demanding conditions of cultivation, high yields, rapid recoupment of costs, considerable nutritional value and rich chemical composition [1].

The chemical composition of the cranberry is unique. The cranberry contains mono -, di - and polysaccharides to $4.8-8.1 \%$ per $100 \mathrm{~g}$ of fruit pulp, of which mono- and disaccharides are up to $3.8 \%$, and pectin substances - up to $2.8 \%$ [2].

The cranberries are rich in organic acids (benzoin, citric, apple, oxalic, quinic), according to data [6], the total amount of those is up to $3.5 \%$, and high content of ursolic acid is noted in the pulp of berries [6]. By structure and genetic this ursolic acid is close to many physiologically important hormones, it has mineralocorticoid activity and is capable of delaying the development of aseptic inflammation [7].

The presence of mono- and disaccharides in combination with organic acids form the taste qualities of berries, and hence - the source product as well $[1,2]$. High acidity of pulp of berries creates conditions for prolonged storage of raw materials in fresh state $(8-10)$ months, in frozen - throughout the year [4]. The nutritional and medicinal quality of the berries depends on the degree of maturity of the cranberries. Unripe berries contain little benzoic acid, which is why they quickly deteriorate [7].

The content of vitamins, and especially vitamin $\mathrm{C}$, varies significantly (12-35 $\mathrm{mg} \%$ ) depending on the season. In the berries of the autumn harvest, this vitamin breaks quickly, and in the snow gathering is almost absent [4]. Of vitamins, in addition to vitamin $\mathrm{C}$, thiamine, riboflavin, nicotinic acid, there are routine $(0.53-1.28 \mathrm{mg} \%)$, pantothenic acid, pyridoxine. Recently, the value of cranberries as an important source of phyllohitone (vitamin K1) has been proved, the deficit of which leads to processes of formation of prothrombin of blood, its share in cranberry berries makes $0,8-1,0 \mathrm{mg} \%$ [8].

There are a lot of flavonoids in berries of cranberry that own a powerful antioxidant effect and are useful in the fight against the major ailments of the present - cardiovascular diseases, malignant tumors, infections [9, 10]. Bioflavonoids have a wide range of pharmacological effects. Being powerful natural antioxidants, bioflavonoids protect the cells of our body from the destructive effects of free radicals [11].

In addition to physiological activity, phenolic compounds have important functional and technological properties - these are natural dyes, antioxidants, preservatives. Polyphenols also contain aromas that determine the taste in many foods.

Cranberries contain polyphenolic compounds: anthocyanins - up to $180 \mathrm{mg} \%$, leucoanthocyanins - up to $160 \mathrm{mg} \%$, catechins - up to $260 \mathrm{mg} \%$, paints and tannins - up to $1200 \mathrm{mg} \%$ [1, 12]. Antioxidant, especially polyphenolic components of cranberries, inhibit the growth of cancerous and tumor cells. In addition, polyphenolic compounds cause the coloring properties of semi-finished cranberries, that is, they are natural dyes [13].

The colors of the cranberries are represented by chlorophyll, carotenoids and anthocyanins; when berries are ripening, the chlorophyll content is significantly reduced, and the anthocyanin content increases [4]. The average value of the content of anthocyanins in 
cranberries in terms of cyanidin-3-glucoside is $80 \mathrm{mg}$ of crude weight of berries [14]. Therefore, the use of puree from cranberries as a dye component, along with its other properties, is a promising solution.

Proanthocyanidins contained in the cranberry also act as antioxidants [12]. Due to the increased content of proanthocyanidins and antioxidants per 1 gram of berries (more than in any other fruit), cranberry strengthens the body's defenses in the fight against antiradicals, which are the cause of many chronic diseases $[15,16]$. Therefore, the identification and quantification of phenolic compounds in cranberries must be accompanied by multilateral research.

From literary data it is known that cranberries contain natural antimicrobial components, including benzoic acid [17]. The first mentions of the presence of benzoic acid in the cranberry berries were brought to their articles by the American scientist G. F. Mason [17]. Later, a number of scientists, with the help of modern methods of analysis, determined the quantitative content of this natural preservative. It is known that a significant influence on the amount of benzoic acid is made by conditions of growth, weather characteristics of the growing season, etc. $[2,4]$. Thanks to its antiseptic properties benzoic acid in a cranberry, provides long-term storage of fresh berries. The conducted studies $[18,19]$ of antimicrobial action of cranberry juice have shown that the concentration of juice in the amount of $5.33 \%$ is sufficient to stop the growth of fungi of the genus Candida.

The increase in interest in natural phytonutrients is due both to the rigid regulation of their use in food products, and to the desire of manufacturers to provide products with the status of natural ones [13].

The above information makes cranberry a promising raw material for use in food technology. To date, a large number of studies have been carried out on the study of the chemical composition of cranberry, which confirms the content of a wide range of biologically active substances $[20,21]$. Many studies have been carried out on the chemical composition of cranberry, depending on climatic conditions, degree of ripeness, duration and storage conditions $[3,4,24,25]$. But the berries undergo a certain technological treatment and are used in the form of puree, the chemical composition of which can significantly differ from the initial chemical composition of fresh berries [22].

The purpose of the research is to determine the influence of technological treatment of blanching and deaeration on the chemical composition of cranberry puree.

\section{Materials and methods}

\section{Materials that are studied}

Investigated cranberry marsh puree, collected in the Volyn region of Ukraine. The production of cranberry puree was carried out by blasting the berries with sharp steam for 56 minutes, their rubbing and deaeration. Blanching reduced microbial contamination, contributed to the destruction of the membrane, which prevents the penetration of steam into berries, partial denaturation of skin proteins and increase the penetration of tissue. Blanched fruits were rubbed and sent to deaeration. The deaeration process was carried out under vacuum to remove the residual moisture and air to prevent the oxidation of biologically active substances and preserve the color of puree [13]. 


\section{- Food Technology}

\section{Description of techniques}

The mass fraction of dry substances was determined by the refractometric method, the essence of which is to determine the mass fraction of dry matter by the refractive index of its solution [1].

The mass fraction of total sugars and reducing agents was determined by hot titration [2].

Actual acidity was determined by potentiometric $\mathrm{pH}$ method by Lur'ye [3].

Pectin substances were determined by the titrimetric method, which is based on the titration of the alkaline pre-selected and prepared pectin substances before and after hydrolysis. The titration results are proportional to the number of free and esterified carboxyl groups $[2,3,30]$.

The content of food fibers was investigated by the method of hydrolysis of readily soluble carbohydrates with a mixture of concentrated acetic and nitric acids $[1,3]$.

The content of vitamin thiamine $\left(B_{1}\right)$ was determined by the method based on oxidation of thiamine in thiohrum, its extraction in an organic solvent and measuring the intensity of fluorescence.

The method of determining vitamin riboflavin $\left(\mathbf{B}_{2}\right)$ is based on fluorescence

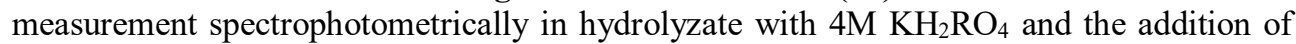
standard riboflavin.

The determination of vitamin niacin (PP) is based on a reaction that takes place in two stages. At the first stage, the interaction of the peridine ring of nicotinic acid with the bromide rodanum occurs. At the second stage, the coloring of the derivative glutacone aldehyde is formed, which is directly proportional to the mass fraction of vitamin and is measured colorimetrically [3].

The amount of ascorbic acid (C) was determined by spectrophotometrically extracted and centrifuged sample with citrate-acetate buffer and 2, 6-dichlorophenylphenol solution, read adsorption at a wavelength of $520 \mathrm{~nm}$ [26].

The mass concentration of phenolic substances was determined by the colorimetric method [26].

To determine the content of bioflavanoid, the following methods were used:

- Ultrasonic high-performance liquid chromatography (UPLC) with diode-matrix detection (PDA), which simultaneously records the electronic absorption spectrum of compounds. The results are obtained on the device of brand WATERS (USA). The analysis was carried out in the gradient mode of changing the composition of the mobile phase (acetonitrile-water). Column ACQUITY UPLC®BEHC ${ }_{18} 1.7 \mu \mathrm{m}, 50 * 2.1 \mathrm{~mm}$;

- Electronic spectroscopy. The results were obtained on the device of brand Specord 210 Plus (Germany);

- Gas chromatography with mass-selective detection and a library of mass spectra before and after acid hydrolysis of source and modified (TMS derivatives) forms. The results were obtained on the Agilent GC/MSD 7890A/5975C with a capillary column of HP5MS [28, 29].

High-performance liquid chromatography (UPLC) [26] was used in this work. To identify compounds with mobile atoms, the method of derivatization (getting derivatives) [26] was used to increase the molecular weight of the starting compound at a known value, to carry out a higher quality chromatography, and also to increase its initial molecular weight - reliable identification. In studies, N-methyl-N-trimethylsilyl-trifluoroacetamide (TMS) reagent was used for this purpose.

The production of ethanol concentrate (organic compounds) was carried out as follows 
[26]: $3,087 \mathrm{~g}$ of cranberry puree are transferred to a $100 \mathrm{~cm}^{3}$ flat bottom flask, filled with 60 $\mathrm{cm}^{3}$ of $96 \%$ ethyl alcohol, and added to the reflux condenser and kept in a boiling water bath for 90 minutes. After that, the water bath is cooled, the condenser is washed with $5 \mathrm{~cm}^{3}$ of ethyl alcohol, and the contents of the flask are transferred (filtered) into a volumetric flask of $100 \mathrm{~cm}^{3}$. Then $35 \mathrm{~cm}^{3}$ of ethanol was added to the flask and the procedure was repeated. The volume of ethanol concentrate was adjusted to $100 \mathrm{~cm}^{3}$.

When conducting an acid hydrolysis [26], the weight of the raw material (approximately $0,992 \mathrm{~g}$ ) weighed to the fourth mark to the nearest quarter is transferred to a $100 \mathrm{~cm}^{3}$ flat bottom flask, $20 \mathrm{~cm}^{3}$ of ethanol, $20 \mathrm{~cm}^{3}$ of distilled water and $10 \mathrm{~cm}^{3}$ of concentrated hydrochloric acid are added. After attaching the flask to the reflux condenser, the mixture is kept in a boiling water bath for 90 minutes. After that, the condenser is washed with $20 \mathrm{~cm}^{3}$ of distilled water, the flask is cooled. The contents of the flask are transferred into a separating funnel through a paper filter of $100 \mathrm{~cm}^{3}$, adding $25 \mathrm{~g}$ of sodium chloride, mixing thoroughly and removing the organic compounds with ethyl acetate (pre-adding water to it), two times for $30 \mathrm{~cm}^{3}$. After drying the ethyl acetate extracts with anhydrous sodium sulfate, the organic solvent is distilled in vacuo. The residual after distillation is dissolved in $50 \mathrm{~cm}^{3}$ of ethanol.

To obtain TMS derivatives, $5 \mathrm{~cm}^{3}$ of ethanol concentrate of the sample is placed in a beaker and at $80^{\circ} \mathrm{C}$ ethanol is removed. To the dry residue, $300 \mu \mathrm{g}$ of anhydrous pyridine and $100 \mu \mathrm{g}$ of N-methyl-N-trimethylsilyl-trifluoroacetamide reagent are added. Beaker is closed and put in UZB for 30 minutes. After this, $1 \mathrm{~cm}^{3}$ of acetonitrite is added to the beaker, mixed and GC/MS is tested according to the procedure described.

The study of the content of natural preservatives (benzoic and sorbic acid) was carried out according to the method described in work [30] and using the high-performance liquid chromatograph Varian 920-LC, the spectrophotometric detector.

To study the microbiological criteria as well as the microbiological stability of the cranberries purée, a research by counting the number of colonies formed as a result of sowing on the nutrient medium was carried out [31]. To determine the diameters of zones of growth retardation of microorganisms, preparations using cranberry puree of different concentrations were used.

\section{Results and discussion}

\section{Chemical composition of cranberries berry puree}

Table 1 shows the main organoleptic characteristics of the obtained puree.

Table 1

Organoleptic characteristics of cranberry puree

\begin{tabular}{|l|l|}
\hline Indicator & Characteristic of the indicator \\
\hline Appearance and consistency & Homogeneous, puree-like, rubbed mass \\
\hline Color & Homogeneous throughout the mass, dark red \\
\hline Scent and taste & Inherent in cranberries, sour \\
\hline
\end{tabular}

Preparation of puree is accompanied by a short-term effect of high temperature during blasting of berries, which may lead to the destruction of biologically active compounds [32]. Therefore, it was advisable to conduct a study of the chemical composition of puree of cranberries, the results of which are given in Table 2 . 
It was found that vitamin $\mathrm{C}$ is most susceptible to destruction, in berries of cranberry its amount was $35 \mathrm{mg} \%$, in puree it remained $2.6 \mathrm{mg} \%$, that is decreased by 13.5 times. This is due to the high thermal stability of ascorbic acid and its degradation under the influence of heat, which accompanies the process of blanching berries with cranes when processed in puree [32].

The content of water-soluble pectin in puree has increased and makes up almost $3.0 \%$ of the mass fraction of dry matter of puree; it is probable [32] during the heat treatment process under the influence of organic acids there was a partial hydrolysis of the protopetyte of plant tissues, as a result of this process, the amount of water-soluble pectin has increased. The increased amount of pectin in puree should have a positive effect on the formation of the composition of the produced and foamy-gelatanious like structures and to prevent the intensive removal of moisture from the product, which will extend the shelf life [23, 33].

The fiber content was $3.1 \%$ to the mass fraction of dry matter with cranberry puree, the total content of dietary fiber in puree exceeded $6.1 \%$. Although they are not absorbed by the body [34], however, they contribute to the implementation of many positive functions: remove toxic metals and radionuclides from the body, inhibit the development of rotting microorganisms, prevent excessive boiling of carbs, and promote the binding of endogenous and exogenous toxins [35].

Table 2

Chemical composition of cranberry puree

\begin{tabular}{|c|c|c|}
\hline Indicator & $\begin{array}{l}\text { Content of substances } \\
\text { per } 100 \mathrm{~g} \text { of puree }\end{array}$ & $\begin{array}{c}\text { Content of substances to } \\
\text { mass fractions of dry } \\
\text { matter of puree }\end{array}$ \\
\hline $\begin{array}{l}\text { Total mass fraction of dry } \\
\text { substances, } \%\end{array}$ & $24,0 \pm 1,5$ & \\
\hline $\begin{array}{l}\text { Mass fraction of water- } \\
\text { soluble dry substances, } \%\end{array}$ & $12,5 \pm 1,5$ & \\
\hline Actual acidity, $\mathrm{pH}$ & $4,37 \pm 0,1$ & \\
\hline Organic acid content, $\%$ & $3,6 \pm 0,5$ & $15,0 \pm 0,5$ \\
\hline Total sugar content, \% & $8,8 \pm 0,5$ & $36,6 \pm 0,5$ \\
\hline $\begin{array}{l}\text { The content of reductive } \\
\text { sugars, } \%\end{array}$ & $6,9 \pm 0,5$ & $28,8 \pm 0,5$ \\
\hline Pectin content, $\Gamma / 100 \Gamma$ & $0,72 \pm 0,1$ & $3,0 \pm 0,1$ \\
\hline Fiber content, $\Gamma / 100 \Gamma$ & $0,75 \pm 0,1$ & $3,1 \pm 0,1$ \\
\hline $\begin{array}{l}\text { Total content of phenolic } \\
\text { substances, } \mathrm{mg} \%\end{array}$ & $235 \pm 9,9$ & $983 \pm 9,9$ \\
\hline $\begin{array}{l}\text { Incl. mass concentration of } \\
\text { anthocyanins, } \mathrm{mg} \%\end{array}$ & $38,4 \pm 0,25$ & $160 \pm 0,25$ \\
\hline \multicolumn{3}{|c|}{ Vitamin content, mg\% } \\
\hline Vitamin C & $2,64 \pm 0,3$ & $11 \pm 0,3$ \\
\hline Thiamine $\left(\mathrm{B}_{1}\right)$ & $0,035 \pm 0,3$ & $0,14 \pm 0,3$ \\
\hline Riboflavin $\left(\mathrm{B}_{2}\right)$ & $0,018 \pm 0,3$ & $0,43 \pm 0,3$ \\
\hline Niacin (PP) & $0,08 \pm 0,3$ & $0,43 \pm 0,3$ \\
\hline Ash,\% & 0,32 & $1,3 \pm 0,3$ \\
\hline
\end{tabular}


That is, it is possible to predict [30] that the adding cranberry puree in the production of food products may partially increase their nutritional value by adding to the product of useful nutritious fibers.

It was determined that in cranberry, $36.6 \%$ of sugars are contained in the mass fraction of dry matter of puree, of which $28.8 \%$ are reductive, namely glucose and fructose, the increase of which is due to partial acid hydrolysis of sucrose during processing berries in puree.

The most common class of organic compounds in plants are acids. Lemon and apple cranberry juice is preferred in puree. The total content of organic acids is $15 \%$ to the mass fraction of dry matter of puree.

Also vitamins - thiamine (B1), riboflavin (B2), niacin (PP) were identified in puree. The amount of ash elements was $1.3 \%$ of the mass fraction of dry matter of cranberry puree.

\section{Identification of bioflavonoids in cranberry puree}

Special attention to the cranberries has recently been crocheted due to the presence of a significant amount of bioflavonoid in it. Therefore, it was advisable to investigate the content of this class of compounds in the investigated berry.

The separation of the ethanol concentrate of cranberry purée using UPLC-PDA method confirms the presence of phenolcarboxylic acids in the sample (the mixture, since the chromatographic peak is highly blurred) - 4.38 minutes (Figure 1, A); Fennel compounds 5.74; 6.23 $\mathrm{min}$ (Figure 1, B); as well as the mixture of anthocyanins -5.29 min (Figure 1, C).

The quantitative correlation between these compounds is determined (Table 3).

Quantitative correlation between compounds according to Figure 1 a, b, c

Table 3

\begin{tabular}{|c|c|c|c|c|c|}
\hline $\begin{array}{c}\text { Duration } \\
\text { of } \\
\text { detention }\end{array}$ & $\begin{array}{c}\text { Mass } \\
\text { fraction of } \\
\text { the } \\
\text { amount, } \%\end{array}$ & $\begin{array}{c}\text { Duration } \\
\text { of } \\
\text { detention }\end{array}$ & $\begin{array}{c}\text { Mass } \\
\text { fraction of } \\
\text { the } \\
\text { amount, } \%\end{array}$ & $\begin{array}{c}\text { Duration } \\
\text { of } \\
\text { detention }\end{array}$ & $\begin{array}{c}\text { Mass } \\
\text { fraction of } \\
\text { the } \\
\text { amount, } \%\end{array}$ \\
\hline \multicolumn{2}{|c|}{ PDA 335.0 nm } & \multicolumn{2}{|c|}{ PDA 350.0 nm } & \multicolumn{2}{|c|}{ PDA 315.0 nm } \\
\hline 4,384 & 88,39 & 5,738 & 39,38 & 5,287 & 100 \\
\hline 5,193 & 11,61 & 6,229 & 37,19 & & \\
\hline & & 6,639 & 23,43 & & \\
\hline
\end{tabular}

After acid hydrolysis, the chromatogram (Figure 2) is characterized by the presence of three anthocyanins with the same nature of the electron spectra, which indicates one nature of the aglucone [12]. It should be noted about the increase in the time of anthocyanins' coming out. This is due to the fact that in the original sample they were glycosylated, that is, they are connected with carbohydrates. Flavonoids, in addition to catechins and leukoanthocyanins, are relatively rare in the free state. Most of them are presented in the form of various $\mathrm{O}$ - and $\mathrm{C}$-glycosides. The diversity of flavonoid glycosides is due to a significant amount of sugars (glucose, arabinose, xylose, etc.) and the ability to attach them to a number of positions of aglycones, as well as the fact that sugars may have different configuration of glycoside bonds and the order of the connections between them [12]. 

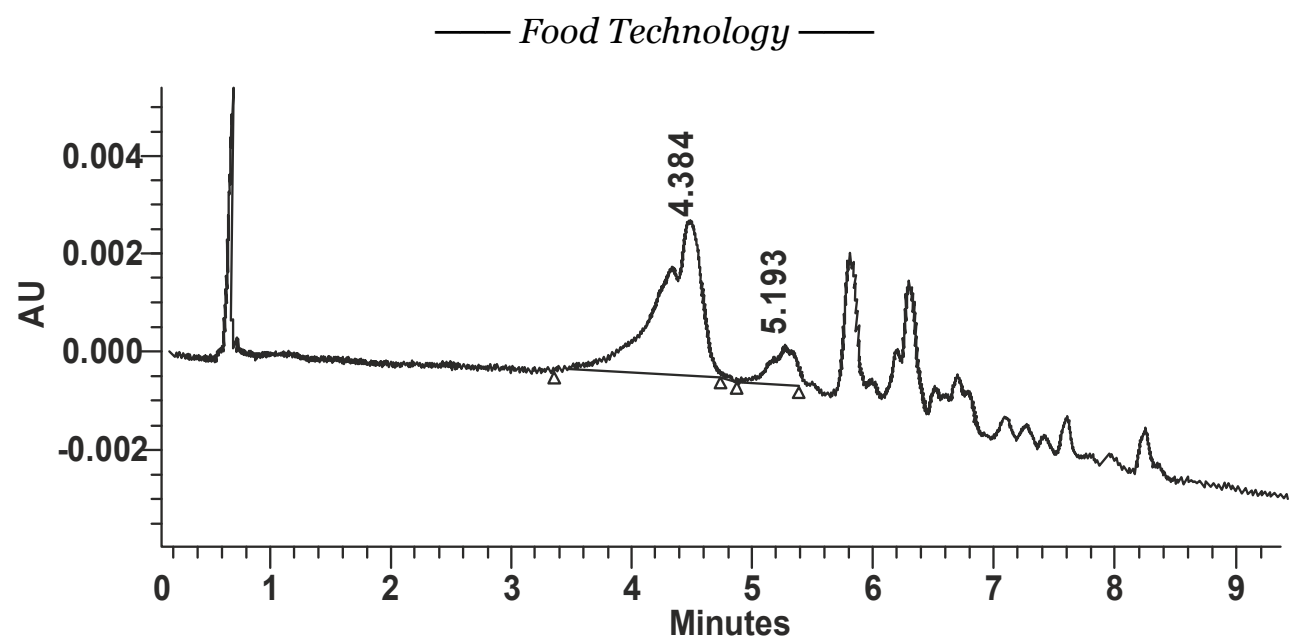

Figure 1a. Chromatogram of the source ethanol concentrate (PDA $335.0 \mathrm{~nm}$ )

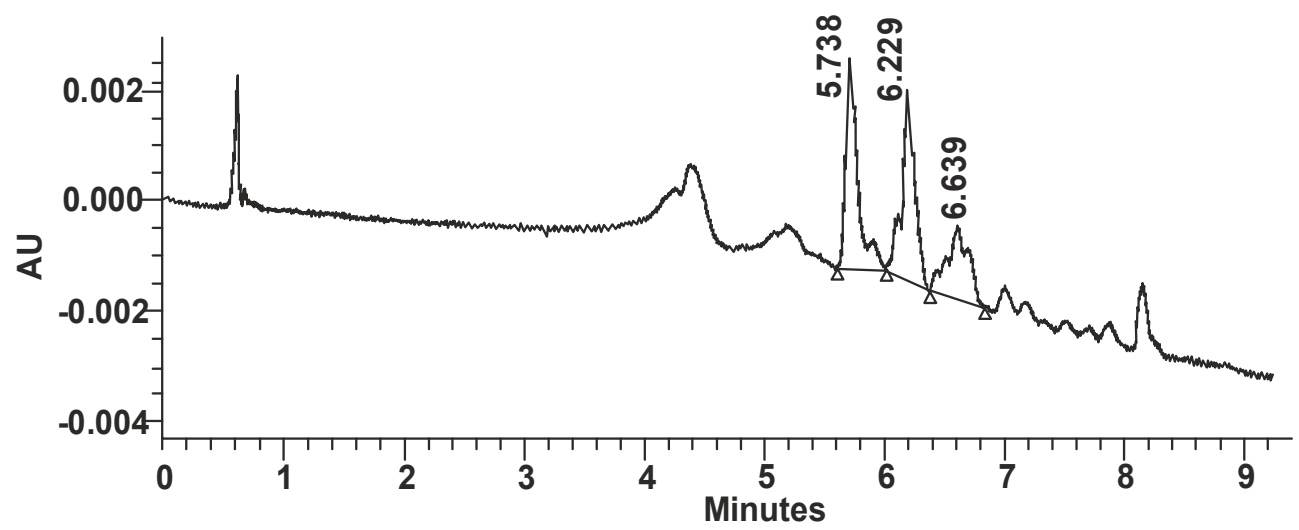

Figure 1b. Chromatogram of the source ethanol concentrate (PDA 350.0 nm)

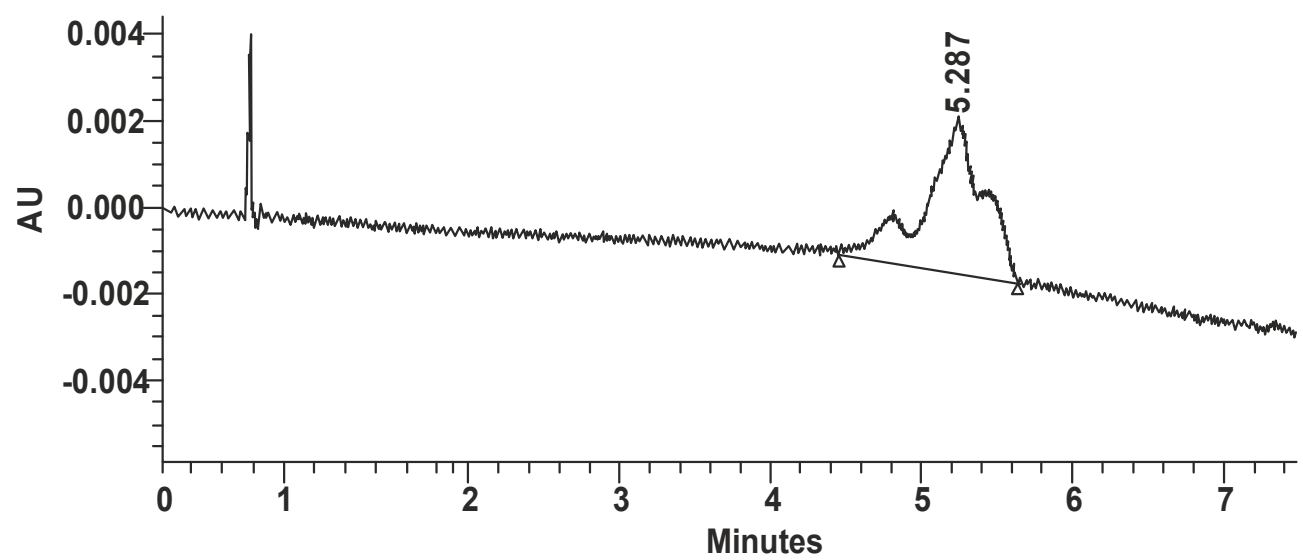

Figure 1c. Chromatogram of the source ethanol concentrate (PDA 315.0 nm) 


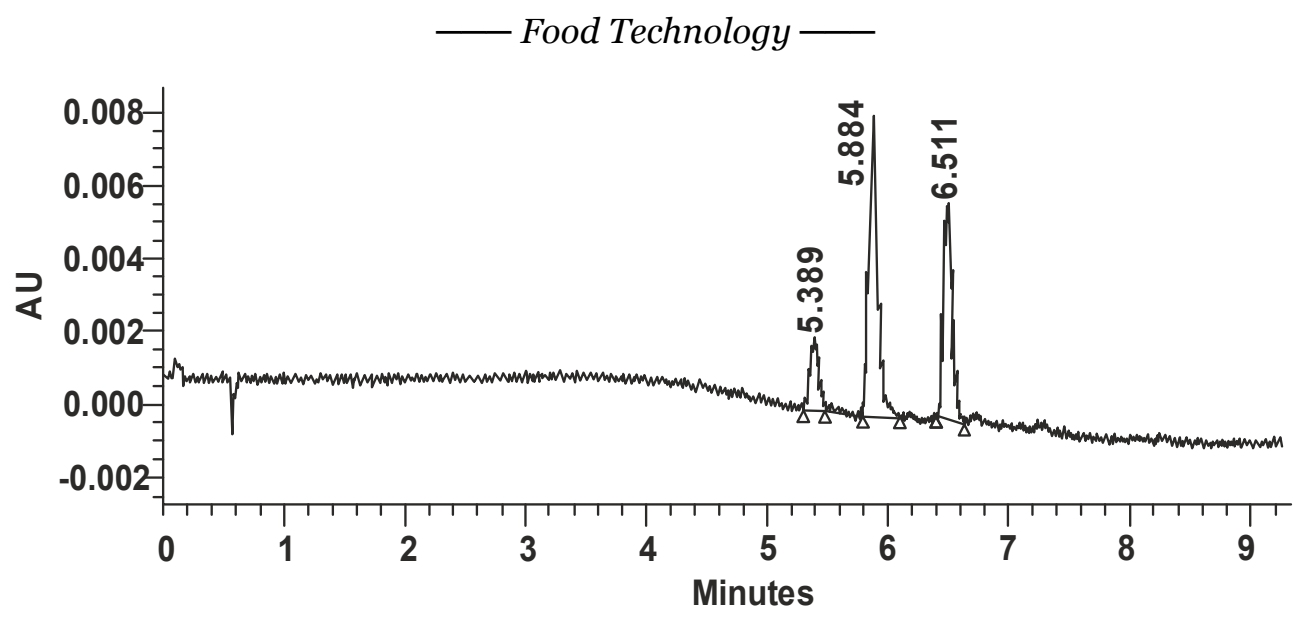

Figure 2. Acid hydrolyzate chromatogram (PDA 350.0 nm)

The quantitative correlation between these compounds is determined (Table 4).

Quantative correlation of compounds in accordance with Figure 2 (PDA $350.0 \mathrm{~nm}$ )

Table 4

\begin{tabular}{|c|c|c|c|}
\hline № & $\begin{array}{c}\text { Volume of sample, } \\
\mathbf{c m}^{\mathbf{3}}\end{array}$ & $\begin{array}{c}\text { Duration of detention, } \\
\mathbf{m i n}\end{array}$ & $\begin{array}{c}\text { Mass fraction of the } \\
\text { amount, } \%\end{array}$ \\
\hline 1 & 1,0 & 5,389 & 10,81 \\
\hline 2 & 1,0 & 5,884 & 52,39 \\
\hline 3 & 1,0 & 6,511 & 36,60 \\
\hline
\end{tabular}

Conducting the TMS derivatization reaction allowed to identify many more compounds: formaldehyde; 3-hydroxybutyric acid; fumaric acid; citric acid. In addition, a number of carbohydrates have been identified: sorbosis, glucose, butanic acid derivatives; dictone propanoic acid; malonic acid; ethyl ether and free citric acid. The total content of phenolic substances in puree of cranberries is up to $235 \mathrm{mg} \%$, therefore, cranberries may be recommended for use in the creation of food products for health purposes [36].

The data of scientific literature [27] indicates the expressed antimicrobial action of cranberries isolated from the fruits of biologically active substances.

Antimicrobial action of benzoic acid and its salts is based on the ability to suppress the activity of enzymes [5]. Specific antibacterial and antifungal efficacy against Escherichia coli and Candida is active 24 hours after use [19]. Benzoic acid is able to block succinate dehydrogenase and lipase, the enzymes that break down fats and starch [19]. It suppresses the growth of yeast and bacteria of butyric fermentation, weakly acts on bacteria of vinegar fermentation and quite slightly - on lactic acid flora and mold [19].

Since berry purees have the optimal composition of nutrients, they are a good environment for the development of microorganisms of damage that can come from the surface of the skin of berries into pulp [37]. Particularly dangerous is the development of some species of fungi of the genus Penicillium, which are capable of secretion of mycotoxin patulin, which has a carcinogenic and mutagenic effect [37]. But in the sources [1, 3, 5, 17], there are discrepancies regarding the data on the quantitative content of preservative in wild 
berries. From a scientific point of view, it was of interest to determine the amount of natural preservatives in puree, which was made from cranberries.

In cranberry puree, benzoic acid was identified in the amount of $122.2 \mathrm{mg} \% \pm 15 \%$ and a small amount of sorbic acid - up to $2.5 \mathrm{mg} \%$. Preservation of these natural preservatives in cranberry puree after the technological processing of berries, confirms preliminary studies of the preservation of the antimicrobial capacity of cranberry juice after autoclaving, are given in [32].

An experiment was conducted to investigate the effect of cranberries on puree yeast of the genus Candida. The genus Candida - the shape of cells is spherical, oval, cylindrical, elongated. Propagated by multilateral budding, as well as by agamous way - blastospores. It forms a pseudo-mycelium, and sometimes a true mycelium. On the surface of liquid substrates forms films: young - white, smooth, old - wrinkled. Assimilates glucose, sucrose, maltose, lactose. After growing in the thermostat, yeast growth retardation zones were observed, which proves the positive effect of cranberries on the growth retardation of the yeast of the genus Candida. Cranberries may be used as a source of natural preservatives, which will help lengthen the shelf life of food products, the dominant factor for which is microbiological damage in the process of storage $[35,36]$.

On the content of nutrients, cranberry puree is a promising raw material for use in creating a wide range of nutritional products for health and functional purposes of extended shelf-life.

\section{Conclusions}

1. Technological reprocessing of cranberry into puree leads to a decrease in the content of ascorbic acid by 13.5 times and to an increase of the content of water-soluble pectin up to $3.0 \%$ to the mass fraction of dry matter of puree.

2. The content of phenolic substances in puree of cranberries is $983 \mathrm{mg} \%$, anthocyanins $160 \mathrm{mg} \%$. The presence of anthocyanin compounds found in the sample is in bound state with citric acid, as well as mono-oxycarboxylic acids.

3. During the processing of cranberry into puree, it preserves natural preservatives contained in fresh berries. Thus, in cranberry puree there is benzoic acid in the amount of $122.2 \mathrm{mg} \% \pm 15 \%$ and a small amount of sorbic acid is available up to $2.5 \mathrm{mg} \%$. The positive effect of cranberry on growth retardation of the yeast of the genus Candida was investigated.

\section{References}

1. Ruse K., Rakcejeva T. (2104) Physical and chemical parameters of latvian fresh cranberries, FOODBALT, pp. 167-171.

2. Khomych G., Matsuk Y., Nakonechnaya J., Oliynyk N., Medved N. (2017), Research of cranberry main indicators of chemical composition and its processing products, EUREKA: Life Sciences, 6, pp. 29-36.

3. Dolly Jean Watson (1997), Chemical Characterization of Wild Maine Cranberries, University of Maine 
4. Celik, H., Ozgen, M., Serce, S., Kaya, C. (2008), Phytochemical accumulation and antioxidant capacity at four maturity stages of cranberry fruit, Scientia Horticulturae, 117 (4), pp. 345-348.

5. Puupponen-Pimia R., Nohynek L., Meier C., Kahkonen M., Hoinonen M., Hopia A., Oksman-Caldentey K.M. (2001), Antimicrobial properties of phenolic compounds from Finnish berries, Journal of Applied Microbiology, 90, pp. 494-507.

6. Jensen D., Krogfelt A., Cornett C. (2002), Hydrophilic carboxylic acids and iridoid glycosides in the juice of American and European cranberries, lingoberries, and blueberries, Journal of Agricultural and Food Chemistry, (50),pp. 6871-6874.

7. Su X., Howell A.B., D'Souza D.H. (2010), The effect of cranberry juice and cranberry proanthocyanidins on the infectivity of human enteric viral surrogates, Food Microbiology, 27 , pp. 535-540.

8. Thimoteo, N. S. B., Scavuzzi, B. M., Simao, A. N. C., Dichi, I. (2017), The impact of cranberry (Vaccinium macrocarpon) and cranberry products on each component of the metabolic syndrome: a review. Nurture, 42 (1), pp. 25-36.

9. Caillet, S., Cote, J., Doyon, G., Sylvain, J.-F., Lacroix, M. (2011), Antioxidant and antiradical properties of cranberry juice and extracts, Food Research International, 44 (5), pp. 1408-1413.

10. Wang L., Tu Y.C., Lian T.W., Hung J.T., Yen J.H., Wu M.J. (2006), Distinctive antioxidant and antiinflammatory effects of flavonols, Journal of Agricultural and Food Chemistry, 54(26), pp. 9798-9804.

11. Majewska E., Skrzycki M., Podsiad M., Czeczot H. (2011), Evaluation of antioxidant potential of flavonoids: an in vitro study, Acta Poloniae Pharmaceutica and Drug Research, 68(4), pp.611-615.

12. Jankowski K., Jocelyn Pare J.R. (1983), Trace glycoside from cranberries (Vaccinium oxycoccus), Journal of Natural Products, (46), pp. 190-193.

13. Jackman R.L., Smith J.L. (1996), Natural Food Colourants. Glasgow: London, pp. 244-309.

14. Pazmiño-Durán A.E., Giusti M.M., Wrolstad R.E., Glória B.A. (2001), Anthocyanins from oxalis triangularis as potentital food colorants. Journal of Food Chemistry, 75(2), pp.211216.

15. Yuan W., Zhou L., Deng G., Wang P., Creech D., Li Sh.(2011), Anthocyanins, phenolics and antioxidant capacity of Vaccinium L. in Texas, USA., Pharmaceutical Crops, 2, pp. $11-$ 23.

16. Johnson-White B., Buquo L., Zeinali M., Ligler F.S. (2006), Prevention of nonspecific bacterial cell adhesion in immunoassays by use of cranberry juice, Analytical Chemistry, 78. pp. 853-857.

17. Mason G. F. (1905), The Occurrence of Benzoic Acid Naturally in Cranberries, Journal of the American Chemical Society, 27(5), pp. 613-614.

18. Côté J., Caillet S., Doyon G., Dussault D., Sylvain J.-F., Lacroix M. (2012), Antimicrobial effects of fractions from cranberry products on the growth of seven pathogenic bacteria, Food Control, 23, pp. 419-428.

19. Lacombe A., Vivian C.H. Wu, Tyler S., Edwards K.(2010), Antimicrobial action of the American cranberry constituents;phenolics, anthocyanins, and organic acids, against Escherichia coli, International Journal of Food Microbiology, 139, pp. 102-107.

20. Kaisu R., Mtt-Riihinen, Afaf Kamal-Eldin, Pirjo H. Mattila et all.(2004), Distribution and Contents of Phenolic Compounds in Eighteen Scandinavian Berry Species, Journal of Agricultural and Food Chemistry, (52), pp. 4477-4486.

21. Määttä-Riihinen K.R., Kähkönen M.P., Törrönen A.R., Heinonen I.M. (2005), Catechins and Procyanidins in Berries of Vaccinium Species and Their Antioxidant Activity, Journal of Agricultural and Food Chemistry, (53), pp. 8485-8491. 
22. Cailleta S., Côtéa J., Doyonb G., Sylvainc J.-F., Lacroixa M. (2011), Antioxidant and antiradical properties of cranberry juice and extracts, Food Research International, 4(5), pp. 1408-1413.

23. Kalinovska T., Obolkina V. (2013), Substantiation of using wine-making secondary products as alternative raw material for confectionery industry, Ukrainian Journal of Food Science, 1(1), pp. 77-80.

24. Wang S.J., Stretch A.W. (2001), Antioxidant capacity in cranberry is influenced by cultivar and storage temperature, Journal of Agricultural and Food Chemistry, 49, pp. 969-974.

25. Gurbuz G., Watkins B. (2002), Controlled-atmosphere effects on postharvest quality and antioxidant activity of cranberry fruits, Journal of Agricultural and Food Chemistry, 50, pp. 5932-5938.

26. Lee H.S. (1993), HPLC method for separation and determination of nonvolatile organic acids in orange juice, Journal of Agriculture and Food Chemistry, 41, pp. 1991-1993.

27. Zuo Y., Wang Ch., Zhan J. (2011), Separation, characterization, and quantization of benzoic acid phenolic antioxidants in American fruit by GC-MS, Journal of Agricultural and Food Chemistry, (50), pp. 3789-3794.

28. Prior R. L., Lazarus S. A., Cao G., Muccitelli H., Hammerstone, J. F. (2001), Identification of Procyanidins and Anthocyanins in Blueberries and Cranberries (Vaccinium Spp.) Using High-Performance Liquid Chromatography/Mass Spectrometry, Journal of Agricultural and Food Chemistry, 49(3), pp. 1270-1276. doi: 10.1021/jf001211q

29. Chen H., Zuo Y., Deng Y. (2001), Seperation and determination of flavonoids and other phenolic compounds in cranberry Juice by high-performance liquid chromatography, Journal of Chromatography, 913(1-2), pp. 387-395.

30. Kalinovska T., Kyianytsia S., Obolkina V. (2013), Doslidzhennia vmistu pektynovykh rechovyn napivfabrykativ z vynohradnykh vychavok ta vyznachennia yikh sorbtsiinykh vlastyvostei, Kharchova nauka i tekhnolohiia, 4(25), pp. 69-74.

31. Oleksiyenko N., Obolkina V., Syvnyi I. (2011), Mikrobiolohichna bezpeka kharchovykh produktiv, Prodovolcha industriia APK, 6, pp. 38-41.

32. Côté J., Caillet S., Dussault D., Sylvain J.-F., Lacroix M.(2011), Effect of juice processing on cranberry antibacterial properties, Food Research International, 44, pp. 2922-2929

33. Syvnyi I., Obolkina V. (2011), Pryrodni konservanty v ozdobliuvalnykh napivfabrykatakh z podovzhenym terminom zberihannia, Prodovolcha industriia APK, 4, pp. $20-22$.

34. Artemio Z., Tulio Jr., Jablonskia J., Jacksona L., Lauren S., Changa C., Edirisinghec I. Burton-Freemanc B. (2014), Phenolic composition, antioxidant properties, and endothelial cell function of red and white cranberry fruits, Food Chemistry, 157, pp. 540-552.

35. Syvnyi I., Oleksiyenko N., Obolkina V. (2012), Vykorystannia piure z zhuravlyny pid chas pryhotuvannia ozdobliuvalnykh napivfabrykativ $\mathrm{z}$ podovzhenym terminom zberihannia, Khlibopekarska i kondyterska promyslovist Ukrainy, 10(95), pp. 6-8.

36. Syvnyi I., Obolkina V., Krapyvnytska I. (2016), Osoblyvosti zberihannia bilkovo-zbyvnoho kremu z dodavanniam horobynovoho ta zhuravlynovoho piure, Prodovolcha industriia $A P K$, 5, pp.27-31.

37. Lipson S.M., Sethi L., Cohen P., Gordon R.E., Tan I.P., Burdowski A., Stotzky G. (2007), Antiviral effects on bacteriophages and rotavirus by cranberry juice, Phytomedicine, 14, pp. 23-30. 